Session 2660

\title{
Engineering Education in Poland
}

\author{
Roman Morawski, Brian Manhire* and Janusz Starzyk* \\ Warsaw University of Technology / *hio University
}

Abstract: This paper describes engineering education in Poland, with a view towards providing a useful overview suitable for comparing the Polish system with that of other countries -- especially the United States. Information provided includes (inter alia): brief descriptions of the overall scheme of education in Poland and the history of higher education there; a description of the types of academic institutions now involved in engineering education in Poland; average qualifications of candidates, entrance requirements and enrollment procedures; fields of study, areas of concentration, degrees offered and related requirements; enrollment data; faculty qualifications and accreditation; and current issues of importance to engineering education in Poland such as job markets and their dynamics.

\section{Poland - an Overview}

The name Polska (Poland) comes from an ancient Slavic tribe known as the Polanie (field or plain dwellers) who settled between the Oder and Vistula rivers in the early Middle Ages [1]. Located in central Europe $\left(49-55^{\circ} \mathrm{N}, 14-24^{\circ}\right.$ E) [2] bordering on the Baltic Sea (Fig. 1), Poland was unified as a kingdom in the $10^{\text {th }}$ century; was a major power in the $15^{\text {th }}$ and $16^{\text {th }}$ centuries until it was divided among other states in the late $18^{\text {th }}$ century and was reborn as a republic in 1918 [3]. Today, the Republic of Poland is slightly smaller (312 $683 \mathrm{sq} \mathrm{km})$ than New Mexico with a (98\% ethnic Polish) population of approximately 38.6 million which is growing at a rate of approximately $0.14 \%$ [2].

Poland's GDP is approximately \$ 5800 per capita (1995 est.) with a growth rate of $6.5 \%$ (1995 est.) and a composition by sectors of $7 \%$ agriculture, $38 \%$ industrial and $55 \%$ service [2]. The country's industrial growth rate is about $10.2 \%$ (1995 est.), and its principle industries include machine building, iron and steel, coal mining, chemicals, ship building, food processing, glass, beverages and textiles. Privatization of the industrial sector is underway, but, as a legacy of the communist era, much of large-scale industry is still state owned [2].

The government that succeeded the collapse of communism in the late 1980s inherited a crisis economy that resulted from years of central planning. Although "shock therapy" measures (e.g., liberalized trade and tightened fiscal policies), taken since 1990 to cope with this inheritance, reduced inflation (approaching $1200 \%$ in 1990) [2], they also reduced industrial pro- 
duction and living standards while increasing unemployment [4]. Poland's GDP fell sharply in 1990 and 1991, but in 1992 Poland became the first country in the region to resume economic growth $(2.6 \%)$ [2]. By 1993 Poland's economy was showing further signs of recovery; the private sector was booming and there was increased interest in Poland by foreign investors [4].

As is true with all nations, Poland's future success depends heavily on its performance as a partner in the global economy. This economy is highly technologically driven - so education, including higher education and its engineering education component, is important to Poland. Poland has a long history of higher education. The Academy of Cracow, called later Jagiellonian University, was established in 1364, as the second university in central Europe (after University of Prague founded in 1348) [1]. With a literacy rate of $99 \%$ and $22 \%$ of its population less than 15 years old [2], Poland has the potential to benefit considerably from the appropriate further education of its citizens.

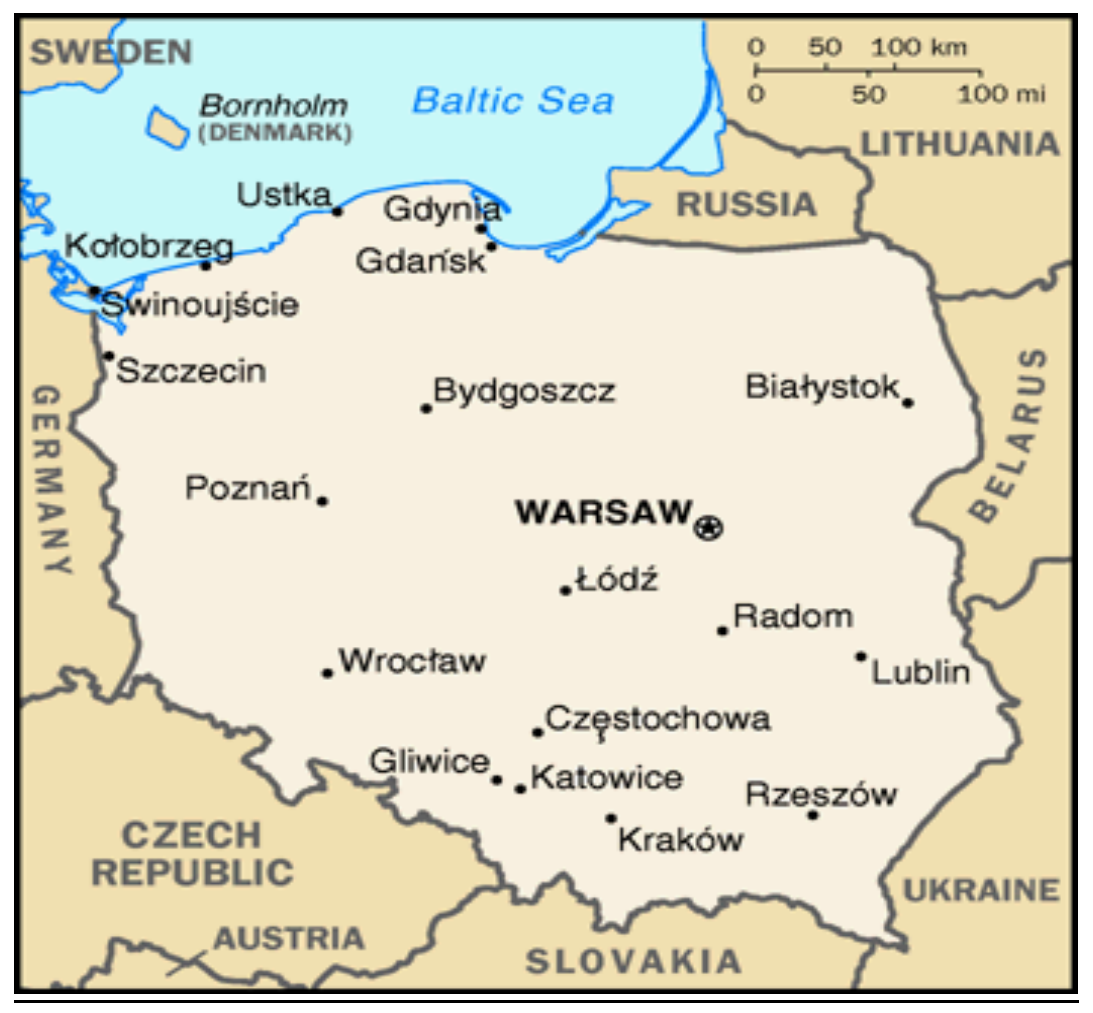

Figure 1. Poland and its environs.

\section{System of Education in Poland}

Education in Poland starts in kindergarten at the age of 3,4 or 5. The obligatory education starts at the age of 6 with a preparatory class (so-called zero class). At the age of 7 students enter primary school which lasts 8 years and prepares them for secondary schools. There are three kinds of secondary schools: general, technical and vocational. General and technical secondary schools 
admit students based on an entrance examination and graduate them within 4 and 5 years, respectively, upon completion of an exit examination and obtaining a certificate called matura. Only the graduates of general and technical schools can be admitted to colleges and universities upon passing an entrance examination.

Unlike the United States, where almost all students attend general-type high schools, in Poland, only $31 \%$ students choose general secondary schools [5]. Traditionally, these schools have been selected by college-bound students since they do not prepare students for specific trades. Since $96 \%$ of all young people attend a secondary school, most of them select various technical or vocational schools. Graduates from general secondary schools can attend two-year colleges to prepare for a specific occupation. Graduates from vocational schools can enroll in three-year technical schools and receive the matura certificate, and become eligible for collegial studies.

Academic institutions in Poland are more specialized than a typical American university. Technical universities or universities of technology, medical schools, agricultural, business, pedagogical, physical education, art colleges and other (military academies, theological academies, and administration colleges) are organized as independent academic institutions with their names related to their specialty areas (e.g., Warsaw University of Technology or The Main School of Agriculture). Universities may still group a number of disciplines (law, sciences, journalism, humanities, and social sciences), but they are not divided into colleges as American universities are.

Admission to most universities is either selective or very selective, by American standards. The major reason for this are admission limits which are set by all academic institutions. While over $70 \%$ of American high-school graduates attend a college or university, less than $20 \%$ of Polish high-school graduates do [5]. Still, this is a significant increase from 10-15\% under the communist system.

In 1996, out of over 900000 Polish students $38 \%$ attended universities, $25 \%$ attended academic institutions involved in engineering education, $12 \%$ business schools, $8 \%$ medical schools, and $17 \%$ were attending all the other schools. Out of this number $9 \%$ of students were enrolled in private academic institutions (mostly business and management schools). The overall level of national government support for higher education in Poland remained in 1996 below $1 \%$ of the GNP, which is significantly less than in Western European countries [6].

\section{Recent History of Higher Education in Poland}

Immediately after the Second World War, higher education in Poland was officially supervised by the Ministry of Education, but in fact final decisions regarding the development and organization of higher education were reserved to the Council of Higher Schools supervised directly by the Prime Minister. The Council, consisting of nine members, in cooperation with several professors and scientists prepared the first Decree on organization of science and higher education, proclaimed on October 28, 1947. The Decree sustained the division of vocational and academic schools, and initiated the process of separating specialized higher schools, in particular medical academies and agricultural academies, from universities. 
After 1947 the Council of Higher Education was replaced by the General Council for Science and Higher Education whose members were appointed by the State President. Its competence was rather wide-ranging: it proposed candidates for the positions of rectors (university presidents), vice-rectors, deans, vice-deans and professors; it approved candidates for scientific degrees; and it influenced the inner organization of particular universities, as well as their development plans, syllabi and curricula.

In April 1950, when the newly-established Polish Academy of Sciences took over the responsibility for scientific research conducted by universities, the administration of higher education was handed over to a new Ministry of Higher Education and Science which in 1951 was transformed into the Ministry of Higher Education. At the same time, the State Commission for Faculty Qualifications was established. It had the authority of approving scientific degrees (formally awarded by the faculty councils) and candidates for scientific titles at universities.

The next change in organization of universities came after political liberalization of 1956, with the Act of October 5, 1958, which operated with minor changes until 1982. At the end of 1966 reorganization of the central management of higher education took place: the Ministry of Science and Higher Education was established. In 1972 it was transformed into the Ministry of Science, Higher Education and Technology.

In May 1982, a new Act regarding higher education was proclaimed. It was prepared during the period of "Solidarity" insurrection, and was aimed at restoring autonomy for academic institutions. However, because it was proclaimed during a period of Martial Law, it was restricted by a number of clauses limiting autonomy. In 1985, a year after matters regarding technology development were removed from the responsibility of the Ministry of Science, Higher Education and Technology, the Ministry of Science and Higher Education was established. Finally, by the fusion with the Ministry of Education (dealing with educational matters below the university level), it was transformed on October 23, 1987, into the Ministry of National Education.

\section{Higher Education in Poland Today}

After the change of political system, a new Act on higher education and a new Act on scientific degrees and titles was passed by the Polish Parliament in 1990. In January 1991 the State Committee for Scientific Research was established. It is the central administrative body responsible for scientific and technical policies, and in particular - for financing research at universities.

The Act of 1990 allowed the foundation and functioning of private higher schools, and extended significantly the autonomy of state academic institutions, resulting in the following:

- The main authorities of each institution, the rector and senate, are elected by the academic community of the institution. 
- The programs of study and numbers of students to be enrolled each year are determined each institution.

- Scientific degrees are conferred by faculty councils under the supervision of the State Accreditation Committee for Scientific Degrees and Titles. The scientific title Professor is conferred by the State President; the nomination procedure is supervised by the State Accreditation Committee for Scientific Degrees and Titles.

- All members of the academic staff, except for full professors, are appointed by rectors. Full professors are appointed by the Minister of National Education in response to nominations made by Rectors.

The Ministry of National Education executes its supervisory power through financial subsidies to State academic institutions. The policy of allocating subsidies in proportion to the number of students was introduced by the Ministry 6 years ago, and has resulted in a significant increase in the number of students in Poland as shown in Tables 1 and 2.

Various trends in the development of Polish higher education after 1989 are tabulated in Tables $1-4$.

Table 1. Polish academic institutions in 1990/91 and in 1996/97 [7].

\begin{tabular}{|c|c|c|c|}
\hline & $1990 / 91$ & $1996 / 97$ & balance \\
\hline \multicolumn{4}{|l|}{ State and private institutions } \\
\hline number of institutions & 92 & 213 & $+95 \%$ \\
\hline number of academic staff & 59000 & 75500 & $+28 \%$ \\
\hline number of students & 403800 & 922200 & $+130 \%$ \\
\hline \multicolumn{4}{|l|}{ State institutions } \\
\hline number of institutions & 90 & 97 & $+7.8 \%$ \\
\hline number of academic staff & 58600 & 68200 & $+16.4 \%$ \\
\hline number of students & 356400 & 779200 & $+119 \%$ \\
\hline \multicolumn{4}{|l|}{ private institutions } \\
\hline number of institutions & 2 & 116 & $\begin{array}{r}+ \\
5700\end{array}$ \\
\hline number of academic staff & 400 & 7300 & $\begin{array}{r}+1 \\
725 \% \\
\end{array}$ \\
\hline number of students & 2400 & 143000 & $\begin{array}{r}+ \\
5860 \\
\%\end{array}$ \\
\hline
\end{tabular}

Table 2. Polish students in 1990/91 and in 1996/97 [7].

\begin{tabular}{|c|c|c||}
\cline { 2 - 3 } \multicolumn{1}{c|}{} & $\mathbf{1 9 9 0 / 9 1}$ & $\mathbf{1 9 9 6 / 9 7}$ \\
\hline total number of students & 403800 & 922200 \\
\hline percentage of evening students & $0.4 \%$ & $4.2 \%$ \\
\hline
\end{tabular}




\begin{tabular}{||c||c|c||}
\hline percentage of correspondence students & $22.4 \%$ & $42.8 \%$ \\
\hline number of engineering students & 79900 & 207500 \\
\hline percentage of evening students & $0.5 \%$ & $4.1 \%$ \\
\hline percentage of correspondence students & $12.4 \%$ & $26.3 \%$ \\
\hline
\end{tabular}

Table 3. Polish higher education in 1990/91 and in 1996/97 - comparative data [5,6,7].

\begin{tabular}{|l|c|c||}
\cline { 2 - 3 } \multicolumn{1}{c|}{} & $\mathbf{1 9 9 0 / 9 1}$ & $\mathbf{1 9 9 6 / 9 7}$ \\
\hline number of students per 100 000 inhabitants & 1054 & 2377 \\
\hline percentage of the high school graduates entering academic institutions & $9.8 \%$ & $19.3 \%$ \\
\hline percentage of the population with university degrees & $6.5 \%$ & $6.9 \%$ \\
\hline total yearly outlay per student in State academic institutions & $\$ 1500$ & $\$ 1900$ \\
\hline
\end{tabular}

\section{Overview of Engineering Education in Poland}

Engineering education at the university level is organized in technical universities and several other specialized schools. Most of them offer a five-year program leading to the Master of Science degree. Undergraduate engineering programs, lasting 3.5-4 years and leading to the Bachelor of Science or equivalent degrees, are offered by some institutions, and their number is growing. Such a program is offered, for example, at the Faculty of Electronics and Information Technology, Warsaw University of Technology, and within 2-3 years will be available at other faculties of this University. Ph.D. degrees are obtained either through doctoral programs lasting 4 years that are organized by universities, or are pursued without a course work, typically by teaching and research associates of academic institutions. In either case, the Ph.D. degree is awarded after passing compulsory examinations, an extensive process of dissertation review (with external reviewers), and a public dissertation defense. The highest formal scientific degree in Poland is the Doctor of Sciences (D.Sc.) which is awarded, upon presentation and public defense of the Doctor of Science thesis (called habilitation), to a professional whose contribution to a field of research is highly recognized. Before this defense can take place, the candidate's entire research and scholarly activities are carefully scrutinized by a panel of reviewers. The D.Sc. degree is normally required for promotion to the full-professor level at academic institutions. Both the Ph.D. and D.Sc. degrees are conferred by faculty councils under the supervision of the State Accreditation Committee for Scientific Degrees and Titles.

Besides mainstream higher education programs, there are continuing education correspondence and evening studies. These studies include about $20 \%$ of all students at technical universities. Classes are organized over the weekend for correspondence students and during the evenings over the week for evening students. Graduates receive a professional engineer diploma. Another form of continuing education in Poland consists of various post-graduate studies which last two or three semesters and terminate with a certificate of completion. Subjects offered at postgraduate studies vary depending on current market needs.

A typical technical university in Poland is divided into faculties (similar to departments at 
American universities) which are subdivided into institutes, that are further subdivided into divisions, although, many institutions have changed this structure. Faculties correspond to various fields of study in engineering like chemical, civil, electrical, etc. Besides these main engineering faculties, technical universities also have specialized centers like biotechnology, applied physics and mathematics, computing services, foreign languages, enterprise development, social sciences, continuing education, physical education, etc. Centers provide service courses and other academic services for universities but, typically, they do not offer their own degree granting programs.

Within engineering education, the following fields of study are available to students at Poland's academic institutions:
1. Agriculture
10. Electrical Engineering
2. Architecture and Urban
11. Electronics and Telecom- munication
18. Mechanical Engi- Planning
12. Environmental Engineer- ing neering
19. Metallurgy
3. Biotechnology
4. Chemical and Process En- gineering
13. Environmental Protection
20. Mining and Geology
21. Ocean Engineering
5. Chemical Technology
6. Chemistry
7. Civil Engineering
8. Computer Engineering
14. Food Technology and Human Nutrition
15. Management and Market- ing
22. Physics
9. Control Engineering and Robotics
16. Materials Engineering
17. Mathematics
23. Science Education
24. Surveying and Map- ping
25. Technical Physics
26. Textile Engineering
27. Transport

According to the official statistics [7], 207500 students studied the above-listed fields at 31 academic institutions. These institutions have the following breakdown:

- 20 State institutions are controlled by the Ministry of National Education (Table 4);

- 4 State institutions are controlled by other ministries (the Ministry of National Defense, the Ministry of Transport and Maritime Economy);

- 7 are private institutions.

As shown in Table 1, more than 100 private higher schools appeared after 1989. However, only the following 7 of them may be considered as related to engineering education:

- Higher School of Mathematics and Applied Computer Engineering in Bialystok,

- Bielska Higher School of Business and Computer Engineering in Bielsko-Biala,

- Higher School of Computer Engineering and Management in Bielsko-Biala,

- Higher Technical School in Głogow,

- Higher School of Computer Engineering and Management in Rzeszow,

- Polish-Japanese Higher School of Computer Engineering in Warsaw,

- Higher School of Computer Engineering and Management in Warsaw.

It should be noted that the above-listed higher schools are formally on the same academic level as universities. All other private higher schools in Poland are involved in non-engineering education, mostly in business- and management-related disciplines. 
Table 4. The academic institutions involved in engineering education that are controlled by the Ministry of National Education (if two dates are given in the third column, then the first of them refers to the foundation of an institution as an engineering college).

\begin{tabular}{|c|c|c|c|c|c|}
\hline & academic institution & $\begin{array}{l}\text { foundation } \\
\text { date }\end{array}$ & fields of study & $\begin{array}{c}\text { number of } \\
\text { academic } \\
\text { staff } \\
\end{array}$ & $\begin{array}{c}\text { number } \\
\text { of } \\
\text { students } \\
\end{array}$ \\
\hline 1 & $\begin{array}{l}\text { Academy of Mining and Metallurgy } \\
\text { in Cracow }\end{array}$ & 1919 & $\begin{array}{l}5,7,8,9,10,11,12,15,16,18,19, \\
20,24,26\end{array}$ & 1801 & 17748 \\
\hline 2 & $\begin{array}{l}\text { Agricultural and Technical Acad- } \\
\text { emy in Olsztyn }\end{array}$ & 1950 & $\begin{array}{l}3,7,12,13,14,15,18,24 \\
\text { (+ non-technical fields) }\end{array}$ & 1009 & 9382 \\
\hline 3 & Bialystok Technical University & $\begin{array}{l}1949 \\
1974 \\
\end{array}$ & $1,2,7,8,9,10,11,12,13,15,18$ & 576 & 7589 \\
\hline 4 & Cracow University of Technology & 1945 & $2,4,5,7,9,10,12,15,16,18,27$ & 1086 & 8843 \\
\hline 5 & Czestochowa Technical University & $\begin{array}{l}1949 \\
1955\end{array}$ & $7,8,10,12,15,16,18,19$ & 570 & 8936 \\
\hline 6 & Gdansk Technical University & $\begin{array}{l}1904 \\
1921\end{array}$ & $\begin{array}{l}2,3,5,7,8,9,10,11,12,13,14,15 \\
18,21,25\end{array}$ & 1234 & 12830 \\
\hline 7 & Koszalin Technical University & $\begin{array}{l}1968 \\
1996\end{array}$ & $7,8,9,11,12,15,18$ & 377 & 6858 \\
\hline 8 & Lublin Technical University & $\begin{array}{l}1965 \\
1977\end{array}$ & $7,10,13,15,18,23$ & 525 & 7169 \\
\hline 9 & Lodz Technical University & 1945 & $\begin{array}{l}2,3,4,5,7,8,9,10,11,12,15,16 \\
18,25,26\end{array}$ & 1604 & 21999 \\
\hline 10 & Opole Technical University & $\begin{array}{l}1966 \\
1996\end{array}$ & $7,8,9,10,12,15,18$ & 353 & 5094 \\
\hline 11 & Poznan Technical University & 1918 & $\begin{array}{l}2,5,7,8,9,10,11,12,13,15,16,1 \\
7, \\
18,23,25,27\end{array}$ & 1066 & 9609 \\
\hline 12 & Radom Technical University & $\begin{array}{l}1950 \\
1996\end{array}$ & $5,10,17,18,22,27$ & 547 & 10190 \\
\hline 13 & Rzeszow Technical University & $\begin{array}{l}1963 \\
1974 \\
\end{array}$ & $5,7,10,12,15,16,18$ & 574 & 7437 \\
\hline 14 & $\begin{array}{|lll|}\text { Silesian } & \text { Technical } & \text { University in } \\
\text { Gliwice } & & \\
\end{array}$ & 1945 & $\begin{array}{l}2,4,5,7,8,9,10,11,12,15,16,17 \\
18,19,20,23,25,27\end{array}$ & 1536 & 19628 \\
\hline 15 & Szczecin Technical University & $\begin{array}{l}1946 \\
1955\end{array}$ & $\begin{array}{l}2,4,5,7,8,9,10,11,12,13,15,16 \\
18,21,25,27\end{array}$ & 707 & 8391 \\
\hline 16 & $\begin{array}{l}\text { Swietokrzyska Technical University } \\
\text { in Kielce }\end{array}$ & $\begin{array}{l}1965 \\
1974 \\
\end{array}$ & $7,10,12,15,18$ & 371 & 5061 \\
\hline 17 & $\begin{array}{l}\text { Technical and Agricultural Acad- } \\
\text { emy in Bydgoszcz }\end{array}$ & 1974 & $\begin{array}{l}\text { 5,7,10,11,12,13,15,18,25, } \\
\text { (+ non-technical fields) }\end{array}$ & 620 & 7533 \\
\hline 18 & Warsaw University of Technology & 1915 & $\begin{array}{l}2,3,4,5,7,8,9,10,11,12,15,16, \\
17,18,23,24,25,27\end{array}$ & 2582 & 21248 \\
\hline 19 & Wroclaw Technical University & 1945 & $\begin{array}{l}2,3,4,5,6,7,8,9,10,11,12,13,1 \\
5, \\
16,17,18,20,23\end{array}$ & 1944 & 17174 \\
\hline 20 & Zielona Gora Technical University & $\begin{array}{l}1965 \\
1996\end{array}$ & $7,8,10,12,15,17,18$ & 410 & 6454 \\
\hline & & & Total & 19492 & 219173 \\
\hline
\end{tabular}




\section{Studying Engineering in Poland}

The candidates for studying engineering in one of the academic institutions mentioned in Table 4 must pass an entrance examination or an equivalent formal procedure verifying their qualifications - which must include a significant amount of knowledge and skills in mathematics, and physics or chemistry (depending on the chosen field of study). The candidates for studying in the field of Architecture and Urban Planning should, moreover, demonstrate exceptional skills in drawing. The results of entrance examinations are used for composing a ranked list for filling a pre-defined number of places with the best candidates. Thus the rate of acceptance depends on the candidates-to-places ratio. This ratio dropped significantly in the 90 s because of the considerable increase in the number of places and a general decline in interest for studying engineering. The latter phenomenon is closely related to the economic transformation of Poland after 1989 which included:

- abandoning the system of central planning,

- development of the private sector of the economy,

- development of the banking system,

- opening free markets for goods and services,

- the introduction of international economic cooperation.

This transformation provoked a growing demand for graduates in business-related and management-related disciplines; i.e., it created a new market of jobs which are much more lucrative than engineering jobs. Consequently, the number of candidates for engineering studies average at 0.9-1.5 per place while the number of candidates for law, economy, business management or, more recently, sociology has been for years at the level of 5-15 per place. A few exceptions are: computer engineering, telecommunications and environmental engineering, environment protection, and some other fields of particular importance during the economic transformation.

An attractive opportunity for talented youth for exemption from entrance examinations is entailed by the annual contests for secondary school students, called Olympiads. The olympiads are organized in 26 fields of knowledge, out of which 6 are related to engineering: Olympiad of Mathematics, Olympiad of Physics, Olympiad of Chemistry, Olympiad of Computer Engineering, Olympiad of Technology and Olympiad of Civil Engineering. The winners of these 6 contests are privileged to enter most engineering faculties without any examination, and those participants who reached the final stage of the contest are exempted from examination [9].

Except for repeated courses, the regular studies (day studies) in State academic institutions are free of charge for Polish citizens. The cost of living in Polish academic cities is, however, relatively high and approaches the cost of living in Germany or France while the average family income remains far below the income level in these countries. Thus financial aid for students is of crucial importance to Polish higher schools. The following forms of financial support are available for Polish students:

- scholarships (derived from the State subsidy) granted by the Deans to students obtaining the best study scores (SS); 
- scholarships (derived from the State subsidy) granted by the Deans to students whose (or whose families') income is below a pre-defined level (SI);

- scholarships granted by companies to the students interested in the jobs offered by those companies (SC);

- grants for the students whose financial situation has deteriorated incidentally (GI);

- low-cost accommodation in students dormitories and low-cost board in students canteens;

- special low-interest loans offered by several banks (since 1995).

Some statistical data characterizing the financial support for Polish students are given in Table 5.

Table 5. Financial support for students of engineering in 1996/97.

\begin{tabular}{|l||c|c|c|c|c|c|c||}
\cline { 2 - 8 } \multicolumn{1}{c|}{} & \multicolumn{6}{c||}{ percentage of students receiving financial support } \\
\cline { 2 - 9 } \multicolumn{1}{c|}{} & SS & SI & SC & SS\&SI & SS\&SC & SI\&SC & GI \\
\hline $\begin{array}{l}\text { in all academic } \\
\text { institutions }\end{array}$ & $9.3 \%$ & $6.2 \%$ & $.0008 \%$ & $2.6 \%$ & $0.04 \%$ & $0.05 \%$ & $3.1 \%$ \\
\hline $\begin{array}{l}\text { in engineering education } \\
\text { institutions }\end{array}$ & $9.9 \%$ & $7.8 \%$ & $0.04 \%$ & $3.4 \%$ & $0.11 \%$ & $0.22 \%$ & $3.9 \%$ \\
\hline \hline
\end{tabular}

The mobility of Polish students is relatively limited, especially by American standards. Accommodation-related problems, inherited from the communist era, still significantly influence the choice of academic institution by the candidates for studies who tend to live with (or near) their families. As a rule, the students complete all their studies at one academic institution. However, the implementation of the Trans-European Mobility Scheme for University Studies (TEMPUS) has resulted in a significant increase in the number of Polish students studying abroad (3 538 in 1996/97 [7]).

\section{Comparison of Poland and the United States}

Poland's population (38.6 million) is about $15 \%$ of that of the United States (250 million) [2] and is growing at a rate of about $0.14 \%$ versus $0.91 \%$ for the United States [2]. In both Poland and the United States, $22 \%$ of the population is less than 15 years old and the literacy rate is about the same as well (99\% for Poland, $97 \%$ for the United States) [2]. Poland's per capita GDP of $\$ 5800$ is about $21 \%$ of that of the United States (\$27 500, 1995 est.) [2].

Statistics regarding higher education in the United States for the 1994-95 academic year are presented in Table 6 [2].

Comparing Tables 1- 3 with Table 6, one may note that a number of comparisons reflect the difference in the populations of Poland and the United States. For example, the number of academic institutions and total enrollment in Poland (213 and 922 200) is about $5.7 \%$ and $6.5 \%$ respectively of its United States counterparts (3 706 and 14261 781). However, Polish enrollment has grown $130 \%$ over the past six years whereas United States enrollment has grown $16.5 \%$ in the past ten years. 
Table 6. Higher Education in the United States in 1994/95 [11]

\begin{tabular}{|c|c|c|c|}
\hline \multicolumn{4}{|l|}{ academic institutions } \\
\hline number of colleges and universities & 3706 & \multicolumn{2}{|c|}{$\begin{array}{l}45 \% \text { public, } 55 \% \text { pri- } \\
\text { vate }\end{array}$} \\
\hline total expenditures & $\$ 182968610000$ & \multicolumn{2}{|c|}{$\begin{array}{l}63 \% \text { public, } 37 \% \text { pri- } \\
\text { vate }\end{array}$} \\
\hline State funds for higher-education & $\$ 46507624000$ & \multicolumn{2}{|c|}{ operating expenses } \\
\hline number of full-time faculty members & 526222 & \multicolumn{2}{|c|}{24680 in engineering } \\
\hline students and degrees & undergraduate & graduate & professional \\
\hline total enrolment & 12231719 & 1732470 & 297592 \\
\hline total degrees conferred & 1699825 & 442075 & 75800 \\
\hline engineering degrees conferred & 64574 & 34663 & \\
\hline
\end{tabular}

The total number of institutions and the division between the number of public and private institutions is stable in the United States (3 706 institutions, $78 \%$ public, $22 \%$ private). However, this is not the case in Poland. For example, since 1990/91, the number of private institutions has increased from 2 to 116 (compared to 7 more State institutions) so that the number of academic institutions has more than doubled to 213, of which $46 \%$ are public and $54 \%$ are private (and the percentage of students enrolled in private institutions has increased from $0.6 \%$ to $15.5 \%)$.

As mentioned in Section II., overall government support for higher education in Poland is less than $1 \%$ of the GNP. The total expenditures by U.S. academic institutions in 1994/95 was approximately \$ 182.97 billion (Table 6) - about $2.5 \%$ of the United States GDP (\$7.2477 trillion, 1995 est.) [2] and State funding for higher-education operating expenses (approximately $\$ 46.508$ billion) was about $0.6 \%$ of the GDP.

Statistics regarding engineering enrollments in the United States for Fall 1996 are given in Table 7 .

Table 7. Engineering enrollments in the United States: Fall 1996 [11]

\begin{tabular}{||l|r||}
\hline \multicolumn{2}{||l||}{ number of undergraduate engineering students } \\
\hline engineering & 356177 \\
\hline engineering technology & 105345 \\
\hline number of engineering graduate students \\
\hline M.S./P.E. & 39079 \\
\hline Ph.D. & 31050 \\
\hline engineering technology & 303 \\
\hline part-time graduate study & 42934 \\
\hline total & 574888 \\
\hline
\end{tabular}

Comparing Table 2 with Table 7, one may note that the number of students enrolled in engineering in Poland (207 500) is about 36 \% of U.S. engineering enrollment (574 888). Fur- 
thermore, engineering enrollment in Poland has grown $160 \%$ since 1990-91. However, U.S. engineering enrollments have been described as currently being in a continuing period of stagnation [11]. For example, over the past year engineering enrollment in the U.S. has declined $2 \%$ at the undergraduate level and $5 \%$ at the graduate level (and graduate enrollment has declined for four consecutive years) [11].

\section{Conclusion}

Engineering education continues to be an important component of higher education in Poland. Since changing its political system, Poland has entered a period of considerable change in its economy. The demands of this economy are driving the country's high growth rate in higher education. As its former command economy becomes a more market (and globally) driven economy, there is increasing demand for trained professionals in fields such as business, management and technology. In addition to fueling Poland's dramatic growth in the number of students enrolled in higher-education, this demand is driving curricular changes fostering further synergy between engineering education and Poland's changed economy. For example, the Master's degree has traditionally been the entry-level qualification for engineering professionals in Poland. Now however, there is growing interest in producing engineers more quickly by way of Bachelor's degree programs.

Poland's future is inexorably tied to its decision to return to a more democratic political system and its concomitant market economy. The country's engineering education resources, as described herein, are sufficiently robust to play an important role in meeting the challenges that lie ahead and will thus help ensure Poland's future success.

\section{References}

[1] Microsoft Encarta'95 (CD-ROM), Microsoft Corporation; Redmond, WA, USA, 1995.

[2] The 1996 World Factbook, (US) Central Intelligence Agency Worldwide Web Site http://www.odce.gov/cia/publications/nsolo/wfb-all.html, accessed October 8, 1997.

[3] Microsoft Bookshelf(CD-ROM), Microsoft Corp.; Redmond, WA, USA, 1995.

[4] Microsoft Encarta'96 World Atlas (CD-ROM), Microsoft Corp.; Redmond, WA, USA, 1996.

[5] Almanac of International Statistics, Central Statistical Office, Warsaw, 1997 (in Polish).

[6] Finances of the Higher Schools in 1996, Central Statistical Office, Warsaw, 1997 (in Polish).

[7] Higher Schools in the School Year 1996/97, Central Statistical Office, Warsaw, 1997 (in Polish).

[8] Guide-book for Graduates of Secondary Schools - 1997/98, Perspektywy Press, Warsaw 1997 (in Polish).

[9] Guide-book on Subject Contests for Students of Secondary Schools - 1997/98, Perspektywy Press, Warsaw 1997 (in Polish).

[10] The Chronicle of Higher Education (Almanac Issue), Vol. XLIV, No. 1, Aug. 29, 1997.

[11] “Enrollments '96: Inching Downward," ASEE Prism (Magazine), September 1997.

ROMAN Z. MORAWSKI received his M.S. degree (1972) and D.S. degree (1990) from Warsaw University of Technology, and his Ph.D. degree (1979) from Leningrad Institute of Electrical Engineering. Since 1972 he has been with Warsaw University of Technology where he is currently a Professor and Senior Associate Dean at the Faculty of Electronics and Information Technology. His current research is in measurement applications of digital signal processing. He is a Fellow of IEE, a Member of IEEE , and a Member of ASEE. 
BRIAN MANHIRE (bmanhire1@ohiou.edu) received B.E.E, MS and Ph.D. degrees in electrical engineering from The Ohio State University in 1972 and 1980 respectively. He is a Professor of Electrical Engineering in the School of Electrical Engineering and Computer Science at Ohio University (http://www.ohiou.edu) in Athens, Ohio.

JANUSZ A. STARZYK received M.S. degree in applied mathematics and Ph.D. degree in electrical engineering from Warsaw University of Technology, Warsaw, Poland, in 1971 and 1976 respectively. Since 1983 he is with the School of Electrical Engineering and Computer Science, Ohio University, Athens, Ohio, where he is currently a professor of EECS. His current research is in the areas of neural networks, pattern recognition, VLSI, VHDL and FPGA design, computer aided design of analog MOS circuits, and mixed signal testing. 